\title{
Testing the overreaction hypothesis in the mexican stock market
}

\author{
Probando la hipótesis de sobrerreacción en el mercado accionario mexicano \\ Jaime González Maiz Jiménez ${ }^{*}$, Edgar Ortiz Calisto² \\ 'Universidad de las Américas Puebla, México \\ 2Universidad Nacional Autónoma de México
}

Received November 27, 2017; accepted January 14, 2019

Available online January 17, 2019

\begin{abstract}
The objective of this work is to test the overreaction hypothesis in the Mexican Stock Market for the period of 2002-2015, using monthly data and applying the Cumulative Average Residuals (CAR) methodology via the CAPM model and the three-factor model proposed by Fama and French. The CAR model is applied to test how winner and loser portfolios perform during the period under analysis. Overall, the evidence shows that average CAR for the loser portfolio is $0.706 \%$, whereas CAR for the winner portfolio is $0.364 \%$, and that are statistically different; nevertheless, both portfolios are co-integrated. This research contributes to the financial literature identifying overreaction in the Mexican Stock Market during the period examined.
\end{abstract}

JEL code: $\mathrm{G} 15, \mathrm{G} 41$

Keywords: Overreaction; Cumulative average residuals; Mexican stock market

\footnotetext{
*Corresponding author.

E-mail address: jaimemaiz@gmail.com (J. González Maiz).

Peer Review under the responsibility of Universidad Nacional Autónoma de México.

http://dx.doi.org/10.22201/fca.24488410e.2019.1794

0186- 1042/C2019 Universidad Nacional Autónoma de México, Facultad de Contaduría y Administración. This is an open access article under the CC BY-NC-SA (https://creativecommons.org/licenses/by-nc-sa/4.0/)
} 


\section{Resumen}

El objetivo de esta investigación es probar la Hipótesis de Sobrerreacción en el Mercado Accionario Mexicano en el periodo del 2002 al 2015. En particular se utilizan datos mensuales aplicando la metodología de Residuales Promedio Acumulados vía el modelo CAPM y el modelo de tres factores de Fama y French. La metodología de residuales se aplica para analizar el desempeño de los portafolios ganadores y perdedores durante el periodo en cuestión. En general, la evidencia señala que el Promedio de los Residuales Acumulados del portafolio perdedor es de $0.706 \%$, mientras que el Promedio de los Residuales Acumulados del portafolio ganador es de $0.364 \%$, siendo estadísticamente diferentes; sin embargo, ambos portafolios están co-integrados. Está investigación contribuye a la literatura financiera ya que identifica que el Mercado Mexicano sobrerreacciona en el periodo examinado.

Código JEL: G15, G41

Palabras clave: Sobrereacción; Residuales promedio acumulados; Mercado accionario mexicano

\section{Introduction}

An important pillar of contemporary finance is the informational theory of efficient markets which suggests that prices of assets and their markets follow a random and unpredictable trajectory but assimilating and reflecting all the underlying information of an economy which is assumed to be widely distributed. Hence, contrarian to the efficient market hypothesis advanced by Fama $(1965,1970,1980$ and 1991) it is impossible to surpass market returns by applying prediction techniques based on past and even current information. The original development of this theory corresponds to Bachelier (1990) who advanced the first mathematical theory of Brownian motion developing a model on speculative prices based on arguments about fair games. The relevance of his theory remain ignored for many years. Its "rediscovery" largely corresponded to Samuelson (1965) who advanced a proof for a version of the efficient market theory. However, in terms of theory, research and financial practice corresponds to Fama the full development of the informational theory of markets which can be tested in statistical-probabilistic terms.

Specifically, Fama proposes that (a) asset prices adjust quickly to new available information; (b) there is a permanent, continuous market in which transactions are carried out at a price very close to the previous one. The more efficient a market is, the faster it responds to information and therefore the smaller the differences in price changes; and (c) the market has enough liquidity to absorb large volumes of transactions without further price destabilization. By fully reflecting the available information neither persistent trends nor speculative leaps are generated so that assets are traded at their fair price: neither overvalued nor undervalued 
and therefore no gains can be made beyond what the market offers in terms of a balance between the risk-return relationship; the higher the risk the higher the return, levels selected by investors based on their own risk aversion. ${ }^{1}$

The fact that the values reflect their fair price and that their behavior is random does not mean that the selection of investments must be also carried out at random. Price information serves primarily as a screen for asset selection and relevant analysis for the construction of portfolios. Similarly, the fact that a market is efficient does not mean that there cannot exists large deviations. However, the adjustment must be quick thanks to arbitration. Paraphrasing Mandelbrot (1971), essentially in a competitive financial market commodities, stocks, bonds and derivatives must be traded at their fair value; any new information causes imperfections but these should be immediately arbitrated; in the presence of arbitration processes, prices must follow a random walk process.

Numerous studies confirmed EMH, particularly during the 1960's and mid 1970's; recent research has also confirmed this hypothesis. Findings by Konak and Seker (2014) confirm that the performance of the FTSE 100 index during the 2001-2009 period sustain the weak form of EMH. Furthermore, more recently Das, Mokashi, and Culkin (2018) examined the behavior of all stocks of the S\&P 500 index for the period 1963-2016; applying deep learning algorithms (neural networks) to predict market returns these authors conclude that their tests, which use larger information sets tan previously used in weak-form tests of market efficiency, do not uncover strong evidence of market inefficiency.

However, although ample research has confirmed the EMH, this notion has also been under scrutiny since its inception by scholars around the world. Research based on two complementary approaches: empirical-econometric research, and behavioral considerations has revealed the presence of numerous market anomalies. If a market is efficient there should be no systematic differences between the current price of an asset and its value, based on the present value of expected flows. Nonetheless, it has been possible to identify the existence of some anomalies or behavior patterns in financial markets associated with excess gains in the market. Among these systematic patterns of extraordinary gains are: the size of the company (higher yields for small business); the value effect (higher yields associated with higher book value/ market value coefficients), the anomaly of the multiple price/earnings (higher yields for lower multiples); the calendar effects (higher yields in January for small businesses; low yields on Mondays, etc.).

\footnotetext{
${ }^{1}$ His theory initially proposed three hypotheses, known collectively as Efficient Market Hypotheses, and more commonly as EMH: 1) Weak hypothesis, 2) semi-strong hypothesis, and 3) strong hypothesis. The first proposes that the prices are negotiated at their fair price, reflecting all the past information available; the presence of correlation between them $=0$. The semi-strong hypothesis proposes that prices reflect not only all possible past information, but also all current information by adjusting itself quickly to new information. Finally, the strong hypothesis indicates that prices adjust quickly and reflect information that is even partially hidden or internal.
} 
Complementing this line of research, departing from the works by Kahneman and Tvresky (1979) psychological principles built up in Prospect Theory, behavioral finance explained seemingly irrational and illogic decisions by investors, initially applying experimental analysis and furthered by De Bondt and Thaler (1985; 1987), and Thaler (2015). In a nutshell, behavioral finance asserts that investors tend to overreact to unexpected and striking news. It explains market anomalies as a consequence of the special traits of human behavior: emotions, leniency, biases, and illusions cannot be rationalized to the extent that asset prices are not random, for they are as unpredictable as people's reaction to new information is unpredictable as well so that investors make their own decisions based on their own past decisions (Gupta Preetibed, and Poonamlakra, 2014). Under this line of research some phenomena like the disposition effect (investors tend to hold their losing stocks to a greater extent than they hold their winning stocks); the herd behavior of investors (investors tendency to copy major trends without adequate analysis and also might flee massively to other markets overweighting the information received); and finally, overreaction (losers portfolios consistently beat the market, while winners portfolios consistently underperform). This last issue is precisely the theme and contribution of this paper. Motivated by the fact that a limited body of research has been devoted to study market inefficiency in emerging markets from the point of view of behavioral finance, it tests the presence of the overreaction effect in the Mexican stock market applying CAR analysis via Sharpe's CAPM and the three-factor model advanced by Fama and French (1993) which is complemented by co-integration analysis.

The work is organized in five sections. The second section reviews the literature on overreaction in various markets and their different approaches. The third section deals with the methodology and information used. The fourth section examines the results obtained. Lastly, the fifth section presents the conclusions.

\section{Literature Review}

First of all, considering the theory of behavioral finance the works by Schiller $(1981,2000)$, De Bondt and Thaler (1985; 1987), Mullainathan and Thaler (2000), Barberis et al. (1998), Sarpa and Zak (2008), Van Witteloostuijn and Muehlfeld (2008), and Thaller (2015) should be stressed as a point of departure for empirical research. Schiller (1981) argues that real stock prices should equal the present value of rationally expected or optimally forecasted future real dividends; but investors are human beings, and as such, they do not always take decisions rationally, which can then create bubbles in stock prices and deviations from intrinsic values at least in the short-term. De Bondt and Thaler $(1985 ; 1987)$ demonstrated that investors overreact to stock market unexpected news. Mullainathan and Thaler (2000) consider that since agents display human limitations and complications, behavioral economics 
helps to get a complete descriptive theory of market behavior. Furthermore, Barberis et al. (1998) based on psychological evidence, pinpoint that such biases provide important reasons why anomalies characterize the behavior of financial markets. In this respect, Shiller (2000) lists twelve major factors, mostly behavioral, that contributed to the irrational exuberance of the bull market from 1982 to early $2000 .^{2}$ He states that many Wall Street analysts became too optimistic about forecasts of stocks they followed. According to Sarpa and Zak (2008) many behavioral concepts from psychology such as overconfidence and herd mentality are being used by neurofinance in order to understand better the behavior of financial markets. Similarly, Van Witteloostuijn and Muehlfeld (2008) claim that behavioral finance, influenced by cognitive psychology, offers a rich set of insights about human decision-making, and the biases that tend to influence human-decision processes; similarly, other studies find different styles of trading behavior derived from personal psychological traits. Finally, Thaler (2015) asserts that market anomalies are present because people are unpredictable on their decisions.

Based on the cognitive psychology realm, in a breakthrough study, De Bondt and Thaler (1985) constructing "winner" and "loser" portfolios found an efficient market anomaly: the stock market overreacted to the extend that "losers" become "winners" and vice versa within their testing period. Using a similar procedure of that of De Bondt and Thaler (1985), Clare and Thomas (1995), using data from UK, find that losers outperform previous winners over a two year period by $1.7 \%$ per annum. In contrast, in a theoretical paper, Daniel, Hirshleifer and Subrahmanyam (1998) demonstrate that investors tend to overreact to private information signals and under-react to public information signals. Analyzing returns on common stock investments, Barber and Odean (2000), find that overconfident investors are inclined to sell winners too soon and keep losers too long in line with Prospect theory advanced by Kahneman and Tvresky (1979). On the other hand, Balvers, Wu, and Gilliland (2000), studying national index data of 18 countries, find parametric contrarian investment strategies that fully exploit mean reversion buy-and-hold and other standard strategies. Similarly, using a new methodology that takes into account time-varying inflation, Anderson et al. (2003) find evidence towards

\footnotetext{
2 These twelve factors are: 1. The capitalist explosion and the ownership society encouraged stock investing. 2. Cultural and political changes favor business success and a significant rise of materialistic values over the years. 3 . New information technology suggested that new era. Investors viewed the Internet revolution as a game changer that justified the stock market boom. 4. Monetary policy and the Greenspan put took perceived risk out of the equation. 5. The perceived effects of the baby boomer generation. 6. The 1990s surge in business media undoubtedly contributed to an interest in the stock market. 7. Analysts' estimates were routinely overoptimistic in the late 1990s. Analysts were hesitant to issue sell recommendations because many firms also had investment banking ties with the company. Analysts also did not want to offend the company because they might then be cut off from earnings guidance or key information. 8. Defined-Contribution Pension Plans grew and replaced many Defined-Benefit Plans. 9. The number of mutual funds surged. Money moving into these mutual funds from $401 \mathrm{~K}$ 's and individual investors found its way into the stock market to feed the bubble. 10. Benign inflation created the illusion of wealth and prosperity. Shiller's research found that the public associates inflation with economic prosperity and social welfare. Such perceptions promote positive expectations for the economy and the stock market. 11. The explosion of trading volume kept the bid in the bubble. 12. There was an increase in gambling over the years.
} 
market "irrationality" regarding stock price behavior. Applying daily data for 18 countries, Chiang and Zheng (2010) find evidence of herding in advanced and in Asian stock markets, except US and Latin America. Further, Deaves, Lüders and Schröder (2010) show that, as a group, market forecasters are overconfident in the sense that they are miscalibrated, and conclude that market experience exacerbates overconfidence through knowledge deterioration. Baker and Ricciardi (2014) state that both research and clinical evidence confirm that subtle shifts in neurochemistry affect financial decision making. Bordalo, Gennaioli and Shleifer (2018) using a model of credit cycles, establish that credit spreads are excessively volatile, overreact to news, and are subject to predictable reversals. Hassan and Mertens (2017) using a macroeconomic model observe that when prices reflect less information, the conditional variance of stock returns rises, causing an increase in uncertainty and costly distortions in consumption, capital accumulation, and labor supply.

Within the personality psychology dimension, McInish (1980) via game simulation, finds a significant relationship between attitudes toward risk and individual stock selection. Fenton-O'Creevy et al. (2004) interviewing traders and trade managers, found that traders have considerably differences in background, personality, and risk considerations, thus being subject to various degrees of cognitive biases. Following the same line of reasoning, Van Witteloostuijn and Muehlfeld (2008) applying a market experiment find that different personality traits affect distinct components of trading behavior, and hence trading performance. Malmendier and Shanthikumar (2007) using the NYSE trades and quotations database, find that the naïve trading behavior of small investors induces negative abnormal portfolio returns. Further, Williams (2013) observes that when there are exciting new investments whose outcome is unsure, even rational and intelligent professionals can get caught up in herding activities.

Specific research regarding overreaction in emerging markets stand out the works recently delivered by, among others, by Tripathi and Gupta (2009); and Khatua and Pradhan (2014); and Tetik and Özen (2016). Examining whether or not overreaction is present in the Indian Stock Market, Tripathi and Gupta (2009) report the presence of a statistically significant but asymmetric overreaction for the period March 1996-March 2007, using monthly data series. Contrarian investment strategy seemingly is economically profitable, generating abnormally positive returns on market-adjusted as well as risk-adjusted basis which are largely attributable to the extremely positive returns of loser stocks during the test period. It is worth mentioning that the first evidence of market overreaction and superior investment returns achieved by using contrarian investment strategy (buying today's "losers" and selling today's "winners") was reported by De Bondt and Thaler $(1985,1987)$. Their study showed that the U.S. stock market tends to overreact to some big news events regardless of whether the events are positive or negative, and the overreaction leads to abnormal price movements. Similarly, Khatua and Pradhan (2014) analyzed the impact of size, volatility and asymmetry in investors' overreac- 
tion to firm specific news in the Indian stock exchange. The study confirms that excess stock return depends on market volatility and the dependence is more significant for small firms. The overreaction is more accentuated to bad news and this in turn to informational asymmetry. In this context, the magnitude and uniqueness of unspecified events increases uncertainty and information diffusion is more asymmetric, which leads to more stock market overreaction. The study also examines whether there is a relationship between the magnitude of price reversals and the magnitude of gain or loss in the stock market return. Significant cumulative abnormal returns are found, indicating the existence of an overreaction effect. It is also determined that the magnitude of price reversal is inversely proportional to the stock return during the event period. In conclusion, their research offers further knowledge about overreaction effects, which could enable investors to prepare trading strategies for higher returns. In turn, Tetik and Özen (2016) recently investigated the possible existence of over-reactions of the Istanbul 100 index (BIST-100) in relation to the Dow Jones Industrial Average Index (DJIA). The sample study included daily stock indexes comprising the period January 2010 and June 2016. The evidence revealed that for positive changes in the DJIA, the Turkish BIST-100 jumps about 0.033; this overreaction decreases and decays after 60 days. In the case of adverse events the Turkish index shows an abnormal decline valid for 30 days after the event; then the decline is reversed until the 60'ieth day when all losses are compensated. Summing up, their study shows that the BIST 100 index does not comply with the efficient market hypothesis and demonstrate the validity of the overreaction hypothesis.

Norli et. al. (2013) investigates stock overreaction behavior in the Malaysian stock exchange; their evidence confirms the presence of overreaction for both winner and loser portfolios experience reversal behavior even after adjustment for size, which implies that size does not matter. Furthermore, after adjustment for size, loser portfolios outperform winner portfolios in the test period.

Among other important works concerning emerging markets' overreaction must be mentioned Fang (2013) who tested overreaction and underreaction in the Chinese stock market using an ANAR TGARCH model. From the results it is clear that irrespective of the size of the stock, the market underreact to good news and overreacts to bad news; asymmetry in volatility is not significant. The work sheds some light regarding the fact that energy shares, industrial and finance sectors overreact to bad news, the effect being more significant for the finance sector. Also, Wang and Xei (2010) explore the relationship between overreaction and the speed of information diffusion in the Chinese market. Industry-adjusted firm size and residual analyst coverage are employed to proxy the speed of information diffusion for a bull market the evidence for overreaction to bad news and underreaction to good news are significant but it is not so for the bear market. Their work documents strong evidence about the profitability of a monthly contrarian strategy decreases with industry-adjusted firm size or residual analyst 
coverage. Furthermore, the profitability of contrarian strategies survives for a longer horizon for stocks with slower information diffusion than for those with faster information diffusion. This result holds true even if risk, bid-ask spread, lead-lag effect, inventory costs, and limits to arbitrage are properly accounted for. They affirm that their evidence suggests that information environment and information diffusion determine the degree of overreaction. Similarly, dealing with another Asian market, Ruhani, Ahmad, Anusakumar (2011) find strong evidence in favor of the overreaction hypotheses for periods of one to fifty two weeks, using weekly data for the period from January 2000 to October 2010. Overreaction in the Malaysian stock exchange is stronger for holding periods of one to four weeks. The looser stocks experience greater return reversals and overreaction is higher for low volume stocks. Their evidence suggests that investor may be able to obtain significant profits by implementing a short term contrarian strategy (purchasing and selling in contrast to the prevailing sentiment of the time) focused on low volume stocks. Worth mentioning is also the work by Schaub, Lee, and Chun (2015) who examined overreaction based on more than 5 percent increases and decreases in the stock markets of Korea, Hong Kong and Japan. Surprinsingly, their evidence, for the 19852004 period, revealed little to no reversals following days of an excessive increase; however, on the contrary, following days of excessive declines stock índices from the three countries reversed by $35 \%$ to $45 \%$ of the initial loss by the 5 th day of trading after the extreme decline. Overreation following disproportionate declines in the three countries was also confirmed by the regression analysis. Hawaldar, Rohit and Prakash (2017) test the weak form of efficient market hypothesis on the stocks listed in the Bahrain Bourse and using the K-S test they find that in general the stock price movement does not follow a random walk. Chen (2018) finds a strong negative relation between online search frequency and future returns in the Chinese stock market, capturing retail investor overreaction to unexpected signals.

Finally, the works by Soares and Serra (2005), and da Costa, Jr. (1994) must be mentioned. Soares and Serra (2005) investigate the existence of overreaction and underreaction in the Portuguese stock market for a period comprising over sixteen years. They employ several testing methodologies to evaluate the robustness of the results and assess the validity of alternative hypotheses set to explain the continuation and reversal patterns in returns. Their results apparently support in the long run the overreaction hypothesis; there is long term reversion in returns and the effect does not vanish adjusting for risk and other control variables. Value strategies earn positive returns that are not explained by ex-ante risk. Yet most of the results lack statistical significance. Similarly, regarding the short run, the authors find weak evidence in support of overreaction effects that persist; this seems to be associated with an insufficient reaction to earnings announcements surprises. In turn, da Costa, Jr. (1994) examine overreaction for the Brazilian market employing both market adjusted and the standard CAPM adjusted returns for the period 1970-1989. Price reversals in two year returns are found; his 
evidence shows that observed asymmetric price reversals were more pronounced than those reported from the US markets inferring that risk cannot explain the anomaly.

This paper aims to prove that although the Mexican Stock Market might be fairly efficient, there can be important deviations from fundamental values thus showing irrational decisions from investors. In particular, from the behavioral finance point of view, the Overreaction Hypothesis is tested constructing "winner" and "loser" portfolios and check their behavior through time. Notwithstanding the limited body of research regarding Emerging Markets the contribution of this paper is considered relevant to the literature.

\section{Methodology and data description: Construction of winner and loser portfolios}

In order to estimate overreaction this study employs monthly closing stock prices for companies selected from the Naftrac Index, whose objective is to track the Mexican Stock Market Index (IPC); this index is composed of 39 companies, but actually information from 24 companies was retrieved; these enterprises represent $90 \%$ of the total weight of the Naftrac by February 2016. The series were gathered from Economática. To construct winner and loser portfolios, CAR estimations must be first carried out, following the procedure put forth by De Bondt and Thaler (1985) summarized in Table 1; monthly information of a total of 24 stocks, 6 portfolios of 4 stocks each are formed and ranked based on the cumulative excess returns $\left(\mathrm{CAR}_{\mathrm{j}}\right)$ of each stock from 2002 to 2008 ("formation period"). January 2002 data is not included because the study deals with logreturns).

Table 1

CAR estimation Procedure

1. Two models are run: CAPM and three-factor model. One of the two is chosen based, for this paper, on the $\mathrm{R}^{2}$ criteria.

2. For each stock “j”, starting January 2002 and finishing on December 2008 -formation period-, the 83 monthly residual returns $\mathrm{u}_{\mathrm{j} \mathrm{t}}$ are computed.

3. For every stock "j", starting on January 2002 and finishing on December 2008, the cumulative excess returns $\mathrm{CU}_{\mathrm{j}}=\sum_{t=0}^{t=83} u_{j t}$ for the 83 months are estimated. The $\mathrm{CU}_{\mathrm{j}}$ 's are ranked from low to high and portfolios are formed; 6 portfolios of 4 stocks each are created, portfolios A to portfolio $\mathrm{F}$.

4) Once the portfolios are formed within the formation period, the cumulative average returns (CARs), where $C A R=\frac{C U_{n}}{n}$ for the "test period" of $2009-2015$ are computed for portfolios A and F, winner "W" and loser "L" portfolio respectively.

Source: Author's own 
Once the portfolios are built up, within the formation period, the cumulative average returns $\left(\mathrm{CAR}_{\mathrm{s}}\right)$ are computed, where for the "test period" of 2009-2015 for portfolios A and F, winner "W" and loser "L" portfolio respectively. Then research hypotheses can be sated as follows:

$$
\begin{aligned}
& \mathrm{H}_{0}=\mathrm{CAR}_{\mathrm{L}, \mathrm{n}, \mathrm{t}} \leq \mathrm{CAR}_{\mathrm{W}, \mathrm{n}, \mathrm{t}} \\
& \mathrm{H}_{1}=\mathrm{CAR}_{\mathrm{L}, \mathrm{n}, \mathrm{t}}>\mathrm{CAR}_{\mathrm{W}, \mathrm{n}, \mathrm{t}}
\end{aligned}
$$

Finally, in order to check whether or not there is no a log-term relationship between the winner and loser portfolios, the Augmented Dickey fuller test is applied, concretely:

$$
\begin{aligned}
& \mathrm{H}_{0}: \mathrm{u}_{\mathrm{t} \sim \mathrm{I}} \mathrm{I}(1) \\
& \mathrm{H}_{1}: \mathrm{u}_{\mathrm{t} \sim} \mathrm{I}(0)
\end{aligned}
$$

The purpose of applying this test is to prove that the results found in this study can be sustained in the long run and that there was not a matter of chance in a particular timeframe. The econometric models previously identified are, as previously stated, the (univariate CAPM advanced by Sharpe (1964) and Fama and French (1993) 3-factor model. CAPM is an equilibrium risk-return model. For the CAPM is applied an Ordinary Least Squares (OLS) model, taking the following form:

$$
r_{t}=\alpha+\beta x_{t}+u_{t}
$$

Where $r_{t}$ : the return on the asset, $\alpha$ : intercept, $\beta$ : risk premium and $u_{t}$ : error term.

In particular $\beta$-the risk premium-, it is simply the return of the stock market as a whole minus the risk-free rate, where the Certificados de la Tesorería (CETES) were used as a proxy for the latter.

The three factor equilibrium model besides taking into account the market index incorporates two additional factors, namely: the size factor and the value factor. A multivariate model regression model is applied for this particular case, taking the following form:

$$
r_{t}=r_{f}+\beta_{1} x_{1 t}+\beta_{2} x_{2 t}+\beta_{3} x_{3 t}+u_{t}
$$


Where $r_{t}$ : the return on the asset, rf: risk-free rate, $\beta_{1}$ : risk premium, $\beta_{2}$ : size factor, $\beta_{3}$ : value factor and $\mathrm{u}_{\mathrm{t}}$ : error term.

Particularly the $\beta_{1}$-the risk premium-, it is simply the return of the stock market as a whole minus the risk-free rate, where the Certificados de la Tesorería (CETES) were used as a proxy for the latter.

The $\beta_{2}$ : size factor: it represents the market capitalization. Specifically, first the sample was ordered from the highest market capitalization value to the lowest value; secondly, the data was split into two portfolios -high value portfolio and low value portfolio-; and thirdly, the returns of the low value portfolio were subtracted from the high value portfolio.

The $\beta_{3}$ : value factor: it represents the quotient of book value divided by market value (B/M). Explicitly, first for each company the book value of equity was divided by the market value of equity; secondly, a ranking was made -from the lowest to the highest- dividing the portfolio in two parts (low B/M and high B/M) ; and thirdly, the returns of the high $\mathrm{B} / \mathrm{M}$ part were subtracted from the low $\mathrm{B} / \mathrm{M}$ part.

\section{Findings}

Table 2 shows the 24 companies included in the sample period, out of the 39 which compose the Naftrac. Weights in the Nactrac index and weights in the winner and loser portfolios are also shown. In turn, Table 3 identifies the companies comprising each portfolio $\mathrm{A}$ to $\mathrm{F}$ and their respective rankings based on their $u_{t}$. It can be observed that important companies, from both the production and services sectors, are included in each portfolio like is the case of Televisa, Alfa, Grupo Carso, Walmex, Grupo Financiero Banorte, and Cemex, among others.

Table 2

Companies Included in the Sample and Weights in the Portfolios

\begin{tabular}{lllll}
\hline \multicolumn{1}{c}{ Ticker } & \multicolumn{1}{c}{ Name } & Included & Weight in naftrac $\%$ & Total Weight $\%$ \\
\hline FEMSAUBD & $\begin{array}{l}\text { Fomento Económico } \\
\text { Mexicano }\end{array}$ & Yes & 14.3 & \\
AMXL & América Movil & Yes & 11.28 & 25.58 \\
GFNorte & Grupo Financiero Banorte & Yes & 8.59 & 34.17 \\
Walmex* & Walmart de México & Yes & 8.36 & 42.53 \\
TlevisaCPO & Grupo Televisa & Yes & 8.28 & 50.81 \\
GMexicoB & Grupo México B & Yes & 5.97 & 56.78 \\
CemexCPO & Cemex CPO & Yes & 4.68 & 61.46 \\
AlfaA & Alfa A & Yes & 4.35 & 65.81 \\
KOFL & Coca-Cola Femsa & Yes & 2.47 & 68.28 \\
BimboA & Grupo Bimbo A & Yes & 2.33 & 70.61
\end{tabular}




\begin{tabular}{|c|c|c|c|c|}
\hline GrumaB & Gruma & Yes & 2.32 & 72.93 \\
\hline GAPB & $\begin{array}{l}\text { Grupo Aeroportuario del } \\
\text { Pacífico }\end{array}$ & Yes & 2.26 & 75.19 \\
\hline KimberA & $\begin{array}{l}\text { Kimberly-Clark de } \\
\text { México }\end{array}$ & Yes & 2.2 & 77.39 \\
\hline GFinburO & Grupo Financiero Inbursa & Yes & 2.01 & 79.4 \\
\hline AsurB & $\begin{array}{l}\text { Grupo Aeroportuario del } \\
\text { Sureste }\end{array}$ & Yes & 1.95 & 81.35 \\
\hline LiverpoolC.1 & El Puerto de Liverpool & Yes & 1.46 & 82.81 \\
\hline $\mathrm{AC}^{*}$ & Arca Continental & Yes & 1.32 & 84.13 \\
\hline Mexchem* & Mexichem & Yes & 1.29 & 85.42 \\
\hline Alsea* & Alsea & Yes & 1.19 & 86.61 \\
\hline Elektra* & Grupo Elektra & Yes & 1.18 & 87.79 \\
\hline GCarsoA1 & Grupo Carso & Yes & 0.91 & 88.7 \\
\hline Peñoles & Industrias Peñoles & Yes & 0.77 & 89.47 \\
\hline ICHB & Industrias $\mathrm{CH}$ & Yes & 0.32 & 89.79 \\
\hline SimecB & Grupo Simec & Yes & 0.11 & 89.90 \\
\hline $\mathrm{ICA}^{*}$ & Empresas ICA & Yes & 0.10 & 90 \\
\hline SanmexB & $\begin{array}{l}\text { Grupo Financiero } \\
\text { Santander México }\end{array}$ & No & 1.98 & 91.98 \\
\hline Pinfra* & $\begin{array}{l}\text { Promotora y Operadora } \\
\text { de Infraestructura }\end{array}$ & No & 1.51 & 93.49 \\
\hline Gentera* & Gentera & No & 1.41 & 94.9 \\
\hline LalaB & Grupo Lala & No & 0.98 & 95.88 \\
\hline OmaB & $\begin{array}{l}\text { Grupo Aeroportuario del } \\
\text { Centro Nor }\end{array}$ & No & 0.7 & 96.58 \\
\hline NemakA & Nemak & No & 0.66 & 97.24 \\
\hline Ienova* & $\begin{array}{l}\text { Infraestructura Energetica } \\
\text { Nova }\end{array}$ & No & 0.63 & 97.87 \\
\hline OHLMex* & OHL México & No & 0.59 & 98.46 \\
\hline SitesL & Telesites & No & 0.48 & 98.94 \\
\hline GFRegio & $\begin{array}{l}\text { Banregio Grupo Finan- } \\
\text { ciero }\end{array}$ & No & 0.35 & 99.29 \\
\hline LabB & $\begin{array}{l}\text { Genomma Lab Interna- } \\
\text { tional }\end{array}$ & No & 0.32 & 99.61 \\
\hline LaComerUBC & La Comer & No & 0.31 & 99.92 \\
\hline MXN & MXN Cash & No & 0.07 & 99.99 \\
\hline Urbi* & Urbi Desarrollos Urbanos & No & 0.01 & 100 \\
\hline
\end{tabular}

Source: https://www.blackrock.com/mx/productos/251895/ishares-naftrac-fund. 
Table 3

Ranking of portfolios based on $\mathrm{CU}_{\mathrm{s}}$

PORTAFLIO A: Televisa, Simec, Gruma and ICA

PORTFOLIO B: Alfa, Bimbo, Alsea and Grupo Inbursa

PORTFOLIO C: Asurb, GCarso, AMXL and Kimber

PORTFOLIO D: Femsa, GMéxico, Walmex and ICH

PORTFOLIO E: Elektra, GFNorte, Liverpool and KOFL

PORTFOLIO F: Peñoles, Mexichem, AC and CEMEX

Source: Author's own

Handling the data also includes identifying whether the CAPM model or else the three-factor model fits better for the series of each company. The $\mathrm{R}^{2}$ criteria was used for this purpose. Table 4 summarizes results associated with this research phase. ${ }^{3}$

Table 4

Best models according to the $\mathrm{R}^{2}$ criteria

\begin{tabular}{|c|c|c|}
\hline Company & CAPM & 3 -factor-model \\
\hline Elektra & & $\mathrm{X}$ \\
\hline Simec & & $\mathrm{X}$ \\
\hline Asurb & & $\mathrm{X}$ \\
\hline GFInbursa & $\mathrm{X}$ & \\
\hline GCarso & $\mathrm{X}$ & \\
\hline Walmex & & $\mathrm{X}$ \\
\hline Bimbo & & $\mathrm{X}$ \\
\hline América Móvil & $X$ & \\
\hline Cemex & & $\mathrm{X}$ \\
\hline ICA & & $\mathrm{X}$ \\
\hline Peñoles & & $\mathrm{X}$ \\
\hline Alfa & & $\mathrm{X}$ \\
\hline GMéxico & & $\mathrm{X}$ \\
\hline GFNorte & & $\mathrm{X}$ \\
\hline Kimberly & & $\mathrm{X}$ \\
\hline Femsa & & $\mathrm{X}$ \\
\hline KOFL & $\mathrm{X}$ & \\
\hline
\end{tabular}




\begin{tabular}{ll} 
ICH & $\mathrm{X}$ \\
Televisa & $\mathrm{X}$ \\
AC & $\mathrm{X}$ \\
Mexichem & $\mathrm{X}$ \\
Alsea & $\mathrm{X}$ \\
Gruma & $\mathrm{X}$ \\
Liverpool & $\mathrm{X}$ \\
\hline
\end{tabular}

Source: Author's own

Tables 5 and 6 include the descriptive statistics and the correlation matrix respectively.

Table 5

Descriptive Statistics

\begin{tabular}{|c|c|c|c|c|c|c|}
\hline & $\begin{array}{c}\text { RPORTFOLIO } \\
\text { A }\end{array}$ & $\begin{array}{c}\text { RPORTFOLIO } \\
\text { B }\end{array}$ & $\begin{array}{c}\text { RPORTFOLIO } \\
\text { C }\end{array}$ & $\begin{array}{c}\text { RPORTFOLIO } \\
\text { D }\end{array}$ & $\begin{array}{c}\text { RPORTFOLIO } \\
\text { E }\end{array}$ & $\begin{array}{c}\text { RPORTFOLIO } \\
\text { F }\end{array}$ \\
\hline Mean & 1.042214 & 2.266631 & 1.585577 & 1.453778 & 1.363431 & 1.173762 \\
\hline Median & 0.673683 & 1.592230 & 1.495744 & 1.444932 & 0.851030 & 1.205041 \\
\hline Maximum & 25.44614 & 20.53547 & 13.28490 & 18.04279 & 16.16431 & 20.04869 \\
\hline Minimum & -1.160 .414 & -1.438 .226 & -6.105 .156 & -9.553 .855 & -9.141 .049 & -1.958 .777 \\
\hline Std. Dev. & 6.557913 & 5.761941 & 4.122293 & 5.119985 & 5.097415 & 6.080402 \\
\hline Skewness & 0.655513 & 0.269319 & 0.139488 & 0.512131 & 0.521451 & 0.050620 \\
\hline Kurtosis & 4.254545 & 4.332155 & 2.670061 & 3.915448 & 3.308406 & 4.511707 \\
\hline Jarque-Bera & 11.38716 & 7.140655 & 0.645625 & 6.526424 & 4.090377 & 7.938635 \\
\hline Probability & 0.003368 & 0.028147 & 0.724110 & 0.038265 & 0.129356 & 0.018886 \\
\hline Sum & 86.50380 & 188.1303 & 131.6029 & 120.6636 & 113.1648 & 97.42223 \\
\hline Sum Sq. Dev. & 3526.510 & 2722.397 & 1393.450 & 2149.568 & 2130.658 & 3031.645 \\
\hline Observations & 83 & 83 & 83 & 83 & 83 & 83 \\
\hline
\end{tabular}

Source: Author's own 
Table 6

Correlation Matrix

\begin{tabular}{|l|c|c|c|c|c|c|}
\hline & $\begin{array}{c}\text { RPORTAFOLIO } \\
\mathrm{A}\end{array}$ & $\begin{array}{c}\text { RPORTAFOLIO } \\
\mathrm{B}\end{array}$ & $\begin{array}{c}\text { RPORTAFOLIO } \\
\mathrm{C}\end{array}$ & $\begin{array}{c}\text { RPORTAFOLIO } \\
\mathrm{D}\end{array}$ & $\begin{array}{c}\text { RPORTAFOLIO } \\
\mathrm{E}\end{array}$ & $\begin{array}{c}\text { RPORTAFOLIO } \\
\mathrm{F}\end{array}$ \\
\hline RPORTAFOLIOA & 1 & 0.684999748 & 0.48325543 & 0.648046305 & 0.523994725 & 0.67191349 \\
\hline RPORTAFOLIOB & 0.684999748 & 1 & 0.611967597 & 0.696779312 & 0.574029348 & 0.698232205 \\
\hline RPORTAFOLIOC & 0.48325543 & 0.611967597 & 1 & 0.627153995 & 0.388558621 & 0.587355356 \\
\hline RPORTAFOLIOD & 0.648046305 & 0.696779312 & 0.627153995 & 1 & 0.661592355 & 0.705377089 \\
\hline RPORTAFOLIOE & 0.523994725 & 0.574029348 & 0.388558621 & 0.661592355 & 1 & 0.612443193 \\
\hline RPORTAFOLIOF & 0.67191349 & 0.698232205 & 0.587355256 & 0.705377089 & 0.612443193 & 1 \\
\hline
\end{tabular}

Source: Author's own

Figure 1 represents how the CARs behave throughout the test period; a visual inspection clearly reveals overreaction, in particular, the figure shows the reversal in the transition period from 2008 to 2009 . On the other hand, when applying the test for difference for the means there is a statistically difference of $0.342 \%(0.706-0.364)-\mathrm{T}$ Value $=-4.46$. Specifically with the Two-sample T test it can be claimed that the CARs for the test period are greater than that of the formation period. Moreover, in terms of difference in variances, based on Levene's test $(p=0.036)$, the series present a contrasting behavior; hence, the investment performance between winner and loser portfolio is different for the test period -. In contrast, when testing for co-integration for formation and test periods for winner and loser portfolios, when both the Engle-Granger test and the Johansen test were run, it is concluded that the series are co-integrated (Tables 7, 8,9 and 10). This means that that the formation and test periods do have a long-term relationship, hence they do not wander apart having a bound. Finally, Portfolio A1 is the winner portfolio in the "formation period" -from 2002 to 2008-, and Portfolio A2 is the same portfolio but in the "test period" -from 2009 to 2015-. On the other hand, Portfolio B1 is the loser portfolio in the "formation period" -from 2002 to 2008-, and Portfolio B2 is the same portfolio but in the "test period" and becomes the winner. 
Table 7

Engle-Granger test for winner portfolio

Date: 11/01/17 Time: 15:18

Series: RPORTFOLIOA1 RPORTFOLIOA2

Sample (adjusted): 284

Included observations: 83 after adjustments

Null hypothesis: Series are not cointegrated

Cointegrating equation deterministics: $\mathrm{C}$

Automatic lags specification based on Schwarz criterion (maxlag=5)

\begin{tabular}{lcccc}
\hline Dependent & tau-statistic & Prob.* & z-statistic & Prob.* \\
\hline RPORTFOLIOA1 & -6.537490 & 0.0000 & -57.17222 & 0.0000 \\
RPORTFOLIOA2 & -7.232372 & 0.0000 & -64.41120 & 0.0000 \\
\hline
\end{tabular}

*MacKinnon (1996) p-values.

Intermediate Results:

RPORTFOLIOA1 RPORTFOLIOA2

\begin{tabular}{lcc}
\hline Rho - 1 & -0.697222 & -0.785502 \\
Rho S.E. & 0.106650 & 0.108609 \\
Residual variance & 50.71461 & 37.94876 \\
Long-run residual variance & 50.71461 & 37.94876 \\
Number of lags & 0 & 0 \\
Number of observations & 82 & 82 \\
Number of stochastic trends** & 2 & 2 \\
\hline
\end{tabular}

**Number of stochastic trends in asymptotic distribution

Source: Eviews 
Table 8

Engle-Granger test for loser portfolio

Date: 11/01/17 Time: 15:20

Series: RPORTFOLIOF1 RPORTFOLIOF2

Sample (adjusted): 284

Included observations: 83 after adjustments

Null hypothesis: Series are not cointegrated

Cointegrating equation deterministics: $\mathrm{C}$

Automatic lags specification based on Schwarz criterion (maxlag=5)

\begin{tabular}{lcccc}
\hline Dependent & tau-statistic & Prob.* & z-statistic & Prob.* \\
\hline RPORTFOLIOF1 & -6.758526 & 0.0000 & -61.07112 & 0.0000 \\
RPORTFOLIOF2 & -8.283125 & 0.0000 & -75.33623 & 0.0000 \\
\hline
\end{tabular}

*MacKinnon (1996) p-values.

Intermediate Results:

RPORTFOLIOF1 RPORTFOLIOF2

\begin{tabular}{lcc}
\hline Rho -1 & -0.744770 & -0.918735 \\
Rho S.E. & 0.110197 & 0.110916 \\
Residual variance & 51.23185 & 35.13428 \\
Long-run residual variance & 51.23185 & 35.13428 \\
Number of lags & 0 & 0 \\
Number of observations & 82 & 82 \\
Number of stochastic trends** & 2 & 2 \\
\hline
\end{tabular}

**Number of stochastic trends in asymptotic distribution

Source: Eviews 
Table 9

Augmented Dickey Fuller test for winner portfolio

Null Hypothesis: RESID_COINT_1 has a unit root

Exogenous: Constant

Lag Length: 2 (Fixed)

\begin{tabular}{|c|c|c|c|}
\hline & & t-Statistic & Prob.* \\
\hline \multicolumn{2}{|c|}{ Augmented Dickey-Fuller test statistic } & -4.214121 & 0.0012 \\
\hline \multirow[t]{3}{*}{ Test critical values: } & $1 \%$ level & -3.514426 & \\
\hline & $5 \%$ level & -2.898145 & \\
\hline & $10 \%$ level & -2.586351 & \\
\hline
\end{tabular}

*MacKinnon (1996) one-sided p-values.

Augmented Dickey-Fuller Test Equation

Dependent Variable: D(RESID_COINT_1)

Method: Least Squares

Date: 06/04/18 Time: 13:05

Sample (adjusted): 483

Included observations: 80 after adjustments

\begin{tabular}{lllll}
\hline Variable & Coefficient & Std. Error & t-Statistic & Prob. \\
\hline RESID_COINT_1(-1) & -0.666965 & 0.158269 & -4.214121 & 0.0001 \\
D(RESID_COINT_1(-1)) & -0.067885 & 0.143802 & -0.472072 & 0.6382 \\
D(RESID_COINT_1(-2)) & -0.079396 & 0.126367 & -0.628296 & 0.5317 \\
C & -0.237791 & 0.812617 & -0.292624 & 0.7706 \\
\hline R-squared & 0.361652 & Mean dependent var & 0.045670 \\
Adjusted R-squared & 0.336454 & S.D. dependent var & 8.901698 \\
S.E. of regression & 7.251176 & Akaike info criterion & 6.848911 \\
Sum squared resid & 3996.046 & Schwarz criterion & 6.968012 \\
Log likelihood & -269.9564 & Hannan-Quinn criter. & 6.896662 \\
F-statistic & 14.35243 & Durbin-Watson stat & 1.934495 \\
Prob(F-statistic) & 0.000000 & & \\
\hline
\end{tabular}

Source: Eviews 
Table 10

Augmented Dickey Fuller test for loser portfolio

Null Hypothesis: RESID_COINT has a unit root

Exogenous: Constant

Lag Length: 2 (Fixed)

\begin{tabular}{|c|c|c|c|}
\hline & & t-Statistic & Prob.* \\
\hline \multicolumn{2}{|c|}{ Augmented Dickey-Fuller test statistic } & -3.834360 & 0.0039 \\
\hline \multirow[t]{3}{*}{ Test critical values: } & $1 \%$ level & -3.513344 & \\
\hline & $5 \%$ level & -2.897678 & \\
\hline & $10 \%$ level & -2.586103 & \\
\hline
\end{tabular}

*MacKinnon (1996) one-sided p-values.

Augmented Dickey-Fuller Test Equation

Dependent Variable: D(RESID_COINT)

Method: Least Squares

Date: 06/04/18 Time: 12:55

Sample (adjusted): 484

Included observations: 81 after adjustments

\begin{tabular}{lllll}
\hline \multicolumn{1}{c}{ Variable } & Coefficient & Std. Error & t-Statistic & Prob. \\
\hline RESID_COINT(-1) & -0.620491 & 0.161824 & -3.834360 & 0.0003 \\
D(RESID_COINT(-1)) & -0.149212 & 0.143684 & -1.038474 & 0.3023 \\
D(RESID_COINT(-2)) & -0.136909 & 0.115606 & -1.184272 & 0.2399 \\
C & -0.018029 & 0.803612 & -0.022435 & 0.9822 \\
R-squared & 0.389531 & Mean dependent var & 0.040995 \\
Adjusted R-squared & 0.365746 & S.D. dependent var & 9.076733 \\
S.E. of regression & 7.228716 & Akaike info criterion & 6.842122 \\
Sum squared resid & 4023.584 & Schwarz criterion & 6.960366 \\
Log likelihood & -273.1059 & Hannan-Quinn criter. & 6.889563 \\
F-statistic & 16.37748 & Durbin-Watson stat & 1.971617 \\
Prob(F-statistic) & 0.000000 & & \\
\hline
\end{tabular}

Source: Eviews 


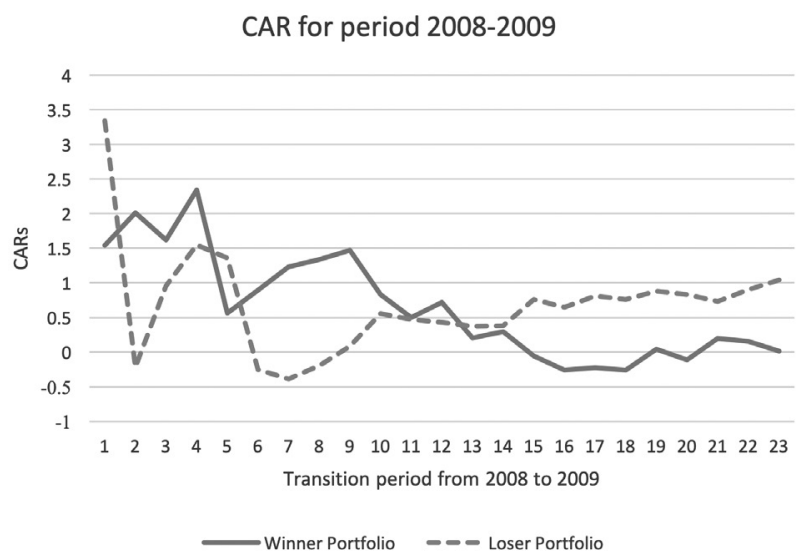

Figure 1. CAR for the transition period $2008-2009$

Source: Eviews

\section{Conclusions}

DeBondt and Thaler (1985) tested overreaction in the stock markets and concluded hypothesizing that markets overreact to unexpected and dramatic news. Following the same line of thought, other studies confirm this issue showing that prices tend to wander away from their fundamental value. Contributing to the financial literature, this research tests the overreaction hypothesis in the Mexican Stock Market applying the CAR methodology with two models -the CAPM and the 3-factor model-, where the best was chosen based on the $\mathrm{R}^{2}$ criteria. Regarding the findings, first, it was found that indeed there are reversals in this market: the winner portfolio becomes loser, and the loser portfolio becomes winner. The difference in means of CARs is $0.342 \%(0.706-0.364)$ in favor of the loser portfolio for the test period, and it is statistically significant; secondly, since the variances of both portfolios differ as well, using the Levene's test, it can be concluded that both portfolios have distinct investment performances; nevertheless, when testing for co-integration applying both the Engle-Granger test and the Augmented Dickey Fuller test, it can affirmed that the portfolios are co-integrated in both periods -formation and testing.

Summing up, this paper sheds some light favoring the viewpoint that overreaction characterizes the Mexican Stock Market. Although, it was demonstrated with both the corresponding tests that the series do have a structural long-term relationship, i.e., the series are co-integrated. Albeit information from all companies could not be retrieved, the results are still representative, notwithstanding that the Mexican stock market is thin and fragile. Shares are actively traded, the market lists less than 250 issuers and its index comprises only 35 firms. Moreover, at any rate findings of this work cast serious doubts against the informational efficiency of the Mexican stock market implying that investors can beat the market by making use 
of the information on past prices of securities due to weak arbitrage processes like Mandelbrot (1971) posits. Consequently, following the same line of thought, further research could be done if taking into consideration the 2008 financial crisis, moreover, research is required in the field of behavioral finance regarding the Mexican Stock Market. Additionally, evidence of this work highlights the need to develop the size, cognizance and competitiveness of the market. Only in this way it can become the engine for mobilizing savings and investment for the provision of long-term financing to enhance national development.

\section{References}

Anderson D., Darrat A. and Zhong M. (2003). Do U.S. Stock Prices Deviate from their Fundamental Values? The Journal of Finance and Banking 27(4), 673-697 https://doi.org/10.2139/ssrn.285714.

Bachelier, L. (1900). Théorie de la spéculation, Annales de l'Ecole Normale Supérieure, 17, 21-86.

Baker H., and Ricciardi V. (2014). The Psychology of Financial Planning. Wiley.

Balvers R., Wu R. and Gilliland E. (2000). Mean reversion across national stock markets and parametric contrarian investment strategies. Journal of Finance 55, 745-772 https://doi.org/10.1111/0022-1082.00225.

Barber B. and Odean T. (2000). Trading is hazardous to your wealth: the common stock investment performance of individual investors. Journal of Finance 55, 773-806 https://doi.org/10.2139/ssrn.219228.

Barberis N., Shleifer A. and Vishny R. (1998). A model of investor sentiment. Journal of Financial Economics 49, 307-343 https://doi.org/10.3386/w5926.

Bordalo P., Gennaioli N. and Shleifer A. (2018). Diagnostic Expectations and Credit Cycles. The Journal of Finance, vol. LXXIII, num. 1, pp. 199-227 https://doi.org/10.1111/jofi.12586.

Chen J. (2018). Online Search Frequency, Retail Investor Overreaction, and the Cross-Section of Stock Returns: Evidence from the Chinese Stock Market. Emerging Markets Finance \& Trade. 54(14), 3.189-3,208 https://doi. org/10.1080/1540496x.2017.1417832.

Chiang T. and Zheng D. (2010). An empirical analysis of herd behavior in global stock markets. Journal of Banking \& Finance 34 (8), 1911-1921 https://doi.org/10.1016/j.jbankfin.2009.12.014.

Clare A. and Thomas S. (1995). The Overreaction Hypothesis and the UK Stock Market. Journal of Business Finance and Accounting 22 (7), 961-973 https://doi.org/10.1111/j.1468-5957.1995.tb00888.x.

Da Costa Jr N. (1994). Overreaction in the Brazilian stock market. Journal of Banking and Finance, 18(4), 633-642 https://doi.org/10.1016/0378-4266(94)00011-5

Daniel, K., Hirshleifer, D,. and Subrahmanyam, A. (1998). Investor psychology and security market under and overreactions. Journal of Finance 53, 1839-1885 https://doi.org/10.1111/0022-1082.00077

Das S, Mokashi, K. and Culkin. R. (2018). Are markets truly efficient? Experiments using deep learning algorithms for market movement prediction. Algorithms 2018, 11, 138. https://doi.org/10.20944/preprints201805.0015.v1

De Bondt W. and Thaler R. (1985). Does the Stock Market Overreact? The Journal of Finance 40(3), 793-805. https://doi.org/10.1111/j.1540-6261.1985.tb05004.x

De Bondt, W., and Thaler, R. (1987). Further evidence on investor Overreaction and stock market seasonality. The Journal of Finance, vol 42, issues 2, pp. 557-581. https://doi.org/10.2307/2328371

Deaves R., Lüders E. and Schröder M. (2010). The dynamics of overconfidence: Evidence from stock market forecasters. Journal of Economic Behavior \& Organization 75(3), 402-412 https://doi.org/10.2139/ssrn.868970

Fama, E.F. 1965. The behavior of stock market prices. Journal of Business 38, pp.34-105. https://doi. org/10.1086/294743

Fama, E.F. 1970. Efficient capital markets: A review of theory and empirical work, Journal of Finance 25, pp. 383- 


\section{7. https://doi.org/10.2307/2325486}

Fama, E. F. 1980. Foundations of Finance. Portfolio Decisions and Securities Prices. Economica. 47 (188) p.484. https://doi.org/10.2307/2553407

Fama, E.F. 1991. Efficient markets: II. The Journal of Finance, vol. XLVI, num. 5, pp. 1575-1617. https://doi. org/10.2307/2328565

Fama E.,. and French K. (1993). Common risk factors in the returns on stocks and bonds, Journal of Financial Economics 3, pp, 3-56 https://doi.org/10.1016/0304-405x(93)90023-5

Fang, Y. (2013). Empirical Investigacion on Overreation and Underreaction in Chinese Stock Market Based on ANAR-TGARCH Model. Journal of Financial Risk Management, Vol. 3, num 4, pp. 7-76. https://doi. org/10.4236/jfrm.2013.24012

Fenton-O'Creevy, M., Nicholson, N., Soane, E., and William, P. (2004). Traders: Risks, Decisions, and Management in Financial Markets. Oxford University Press. https://doi.org/10.1093/acprof:oso/9780199269488.003.0004

Gupta, E., Preetibedi, and Poonamlakra (2014). Efficient market hypothesis v/s behavioral finance. IOSR Journal of Business and Management, vol. 16, Issue 4, pp. 56-60. https://doi.org/10.9790/487x-16445660

Hassan T.and Mertens T. (2017). The Social Cost of Near-Rational Investment. American Economic Review. Vol. 107, num 4, pp. 1059-1103. https://doi.org/10.1257/aer.20110433

Hawaldar I., Rohit T and Pinto P. (2017). Testing of Weak Form of Efficient Market Hypothesis: Evidence from the Bahrain Bourse. Investment Management and Financial Innovations. Vol. 14, num 2, pp. 376-385. https:// doi.org/10.21511/imfi.14(2-2).2017.09

Kahneman, D., and Tversky, A. (1979). Prospect Theory: An analysis of Decision under risk. Econometrica 47, vol. 47, num. 2, pp. 263-292. https://doi.org/10.2307/1914185

Khatua and Pradhan (2014). Indication of Overreaction with or without Stock Specific Public Announcements in Indian Stock Market. Vikalpa, vol. 9, num. 3, pp. 35-49. https://doi.org/10.1177/0256090920140303

Konak, F., Seker, Y., 2014. The efficiency of developed markets: Empirical evidence from FTSE 100. Journal of Advanced Management Science, vol. 2, num. 1, pp. 19-32. https://doi.org/10.12720/joams.2.1.29-32

Mandelbrot, B. (1971), When can Price be arbitraged efficiently? A limit to the validity of the Random Walk and Martingale Models, Review of Economics and Statistics 53, pp. 225-236. https://doi.org/10.2307/1937966

Malmendier U. and Shanthikumar D.M. (2007). Are small investors naïve about incentives? Journal of Financial Economics 85, 457-489. https://doi.org/10.2139/ssrn.817604

Mcinish T.H. (1980). A game simulation of stock market behavior: An extension. Simulations and Games 11, 477484. https://doi.org/10.1177/104687818001100407

Mullainathan S. and Thaler R. (2000). Behavioral Economics. Working paper 7948,. National Bureau of Economic Research (NBER). https://doi.org/10.3386/w7948

Norli, A., Talib, N, Annuar, M, and, Salazi, A, (2013). Overreaction of Syariah Stocks: does Size Matter. International Journal of Economics and Management, vol. 7, num. 1, pp. 123-135. https://www.researchgate.net/publication/285523567_Overreaction_of_syariah_stocks_Does_size_matter Consulted on September 2 of 2017

Ruhani, Ahmad, and Anusakumar, A. (2011). Stock Market Overreaction and Trading Volume: Evidence from Malaysia. Asian Academy of Management. Journal of Accounting and Finance, vol. 7 num. 2, pp. 103 -119. http:// web.usm.my/journal/aamjaf/vol\%207-2-2011/7-2-4.pdf Consulted on September 2 of 2017

Samuelson, P. (1965). Proof that Properly Anticipated Prices Fluctuate Randomly. Industrial Management Review 6, pp. 41-49. https://doi.org/10.1142/9789814566926_0002

Sarpa S. and Zak P. (2008). Neurofinance: Bridging Psychology; neurology, and Investor behavior. Working paper. https://www.coursehero.com/file/20937700/SSRN-id1323051/ Consulted on September 4 of 2017

Schaub, M., Lee, B.S., and Chun, S.E. (2015). Overreaction and seasonality in Asian Stock Indices: Evidence from Korea, Hong Kong and Japan. In Andrew H. Chen, ed. Research in Finance, Vol. 24. Emerald Group Publishing, pp.169-195. https://doi.org/10.1016/s0196-3821(07)00207-9

Sharpe W. (1964). Capital Asset Prices: A Theory of Market Equilibrium under Conditions of Risk. Journal of Finance 3, 425-442. https://doi.org/10.1111/j.1540-6261.1964.tb02865.x 
Shiller, R.J. (1981). Do Stock Prices Move Too Much to be Justified by Subsequent Changes in Dividends?", American Economic Review (June 1981), 71(3): 421-436. https://doi.org/10.3386/w0456

Schiller, R. J. (2000). Irrational Exhuberance. Princeton University Press.

Soares, J.W., AND and Serra, A.P. (2005). "Overreaction" and "Underreaction": - Evidence from the PortugueseStock Market-. Working Paper.CEMPRE, Faculdade de Economia da Universidade do Porto. https://www.researchgate.net/publication/228650891_Overreaction_and_Underreaction-Evidence_for_the_Portuguese_Stock_Market

Tai, Y-N. (2014). Investor overreaction in Asian and US Stock Markets: Evidence from the 2008 financial crisis. The International Journal of Business and Finance Research, vol. 8, num. 3, pp. 71-93. https://papers.ssrn.com/ sol3/papers.cfm?abstract_id=2392454 Consulted on September 10 of 2017.

Tetik, M. and Özen, E. (2016) Overreaction Hypothesis and Reaction of Borsa Istanbul to Dow-Jones. Business and Economic Research, vol. 6, num. 2, pp. 412-423. https://doi.org/10.5296/ber.v6i2.10353

Thaller, R. (2015). Misbehaving: The Making of Behavioral Economics. W.W. Norton Company. https://doi. org/10.5860/choice. 192072

Tripathi, V., and Gupta, S. (2009). Overreaction Effect in Indian Stock Market. Asian Journal of Business and Accounting, Vols. 1-2, pp. 93-114. https://www.researchgate.net/publication/228241373_Overreaction_Effect_ in_Indian_Stock_Market Consulted on October 20 of 2017.

Van Witteloostuijn A. and Muehlfeld K. (2008). Trader personality and trading performance. Working paper 08-28. file://D:/Users/21107/Downloads/rebo_use_dp_2008_08-28.pdf

Wang, C. and Xei, L. (2010). Information Diffusion and Overreation: Evidence from the Chinese Stock market. Emerging Markets Finance and Trade, vol. 46, issue 2, pp. 80-100. https://doi.org/10.2753/ree1540-496x460206

Williams R. (2013). Emotion, Not Rational Logic, Determines the Stock Market. .Psychology Today. Retrieved from: https://www.psychologytoday.com/blog/wired-success/201309/emotion-not-rational-logic-determines-the-stock-market. Consulted on October 27 of 2017.

Yu-Nan, Tai (2014). Investor overreaction in Asian and US Stock Markets: Evidence from the 2008 financial crisis. The International Journal of Business and Finance Research, vol. 8, num. 3, pp. 71-93. Available at SSRN: https://ssrn.com/abstract=2451849 https://papers.ssrn.com/sol3/papers.cfm?abstract_id=2392454 Consulted on October 14 of 2017. 